\title{
The Aboriginal-White Relationship in The Secret River and Carpentaria*
}

\author{
XING Chun-li \\ Tsinghua University, Beijing, China \\ Beihang University, Beijing, China \\ University of New South Wales, Sydney, Australia
}

\begin{abstract}
This paper mainly explores the Australian Aboriginal-white relationship in two novels: The Secret River (2005) by non-Indigenous writer Kate Grenville, and Carpentaria (2006) by Indigenous novelist Alexis Wright, and compares the discursive strategies and narrative devices the authors have adopted to represent whiteness and Indigeneity, one from the European settlers' point of view, the other from the standpoint of an Aboriginal author. In The Secret River, Grenville resorts to the genre of historical novel as a way of reconciling the past. Though the novel challenges the racialised stereotypes of the Aboriginal people by adopting a double perspective (a reconfigured white perspective to refute the colonists' views), the moral ambiguity of the settler identity is still complicit with the colonial discourse. On the other hand, Carpentaria rejects a narrow, essentialist categorization of the Aboriginal people and defamiliarises the concept of whiteness by foregrounding it in a critique rather than as the default norm. Set in a narrative related to the oral tradition, the novel brings Aboriginal cosmology into full play. A comparison of the two novels provides a panoramic view of how the Aboriginal-white relationships are presented through the literary imaginary in Australia.
\end{abstract}

Keywords: whiteness, Indigeneity, double perspective, Aboriginal cosmology, comparison

\section{Introduction}

In the twenty-first century, two Australian writers, Kate Grenville and Alexis Wright, have dealt in depth with the relationships between white and Indigenous people in their award-winning novels, The Secret River and Carpentaria, respectively, both of which have attracted great attention from the academic world.

It is interesting to note that though the two novels are set in different historical periods, The Secret River in the contact zone of more than 200 years ago, and Carpentaria in a modern era when attempts at reconciliation have been made between white and Indigenous people, both of the novels highlight an interaction between the past and the present, and also emphasize people's connections to nature and land.

\footnotetext{
* Acknowledgements: This paper is part of the author's academic studies project, The Nexus of Whiteness and Indigeneity in Contemporary Australian Novels, which is sponsored by the Australia-China Council 2014-2015 Competitive Project Funding. Thanks also go to China Scholarship Council, which has sponsored the author's academic visit in University of New South Wales, Australia in 2015-2016 academic year.

XING Chun-li, Ph.D. Candidate at Tsinghua University, Associate Professor at Beihang University, Visiting Fellow at University of New South Wales.
} 
However, completely different genres and narrative strategies are adopted in the two novels, articulating the voices on two sides, the former from the European settlers' point of view, the latter from the standpoint of an Aboriginal author. A comparison of these discursive strategies and the ways of approaching the past and nature in these two novels may provide a fuller picture of how literary texts in Australia represent the Aboriginal-white relationship from both Indigenous and non-Indigenous perspectives.

Grenville has adopted the genre of historical novel to tease out a sense of guilt over the colonial wrong-doings against the native Australians in the contact zone. A double perspective on the male protagonist William Thornhill's consciousness reexamines the settler psychology and can be regarded as a reconfiguration of whiteness from a postcolonial stance, which acknowledges the central place of the Aboriginal people in the construction of the Australian state and respects the Aborigine as an equal and noble "Other". However, the limited point of view from a white settler has to a large degree distanced from the Aboriginal people's consciousness and the Aboriginal people's voice is seldom heard.

On the other hand, Carpentaria resorts to mixed genres. Though problematically labeled by western critics as an instance of magical realism, the novel is constructed from multiple perspectives and depicts a myriad of Indigenous realities, giving full say to the Aboriginal people. To defy the hegemonic metanarrative, whiteness is foregrounded in a critique instead of as the default norm of perception. Though set in the present, the narrative goes beyond the boundaries of time and space, with the oral tradition, Aboriginal cosmology and legends interwoven into the fabric of narration.

\section{The Double Perspective in The Secret River}

As J. J. Healy (1989) has pointed out, fictions are "narrative battlegrounds in which conscience fought itself to a kind of consciousness", and "the novel itself was a field of consciousness, one which had been alerted into existence by a disturbing experience; the working through of the experience became possible only through the form of the novel” (p. xv).

By resorting to the genre of historical novel, Grenville has teased out the disturbing experience of a settler family in its first contact with the Aboriginal people, and attempted to speak into "the great Australian silence" (Stanner, 1968, as citeded in Kossew, 2007). In her writing memoir Searching for the Secret River (2006), Grenville stated that her intention of writing the novel was to fill that "empty space in my own family story where the Aboriginal people belonged” (2006, p. 193).

The metanarrative of the settlers' discourse observed by Thornhill treats the Aboriginal people as lesser beings: "Men came from all the streets around, cheered to watch this black insect of a man [Scabby Bill] capering before them, a person lower in the order of things even than they were" (Grenville, 2005, p. 92). This statement comes in sharp contrast with Thornhill's own perception of Scabby Bill as having a "fine figure" (Grenville, 2005, p. 90) and the acknowledgement of the "carefully drawn" scars on his chest as "a language of skin", "like the letters Sal had shown him, bold on the white face of the paper” (Grenville, 2005, p. 91). This double perspective acknowledges the competing claims of settlers and Aboriginal people in nineteenth-century Australia, and can be read as "a distinction through which the contemporary liberal settler subject is defined and redefined in settler-colonial cultural texts”, which "signals the emergence of a form of recognition” (Gall, 2008, p. 95).

This double perspective on Thornhill's mind reveals tensions between the hegemonic colonial discourse and 
a reconfigured form of whiteness, thus invoking the past disturbing experience "to deploy its 'presentness'”, and enabling its "transcendence in the search for a more secure and universal value system" (Hutcheon, 1988, p. 88). One perspective of Thornhill's perception shows complicity with the master narrative of the colonizers, which judges the natives by the European norms of value:

It was true the blacks made no fields or fences, and built no houses worth the name, roaming around with no thought for the morrow. It was true that they did not even know enough to cover their nakedness, but sat with their bare arses on the dirt like dogs. In all these ways they were nothing but savages. (Grenville, 2005, p. 229)

The other perspective reconfigures the white norms, paying respect to the Aboriginal people's way of living: "the blacks were farmers no less than the white men were. But they did not bother to build a fence to keep animals from getting out. Instead they created a tasty patch to lure them in. Either way, it meant fresh meat for dinner" (Grenville, 2005, p. 229), and even showing admiration for the nobility of the natives: "Even more than that, they were like gentry. They spent a little time each day on their business, but the rest was their own to enjoy. ... In the world of these naked savages, it seemed everyone was gentry” (Grenville, 2005, p. 230). This reconfiguration of the settler subject's consciousness highlights "the self-destructing tendencies of racial subjectivity" and becomes a "substantial hope of overcoming racism" (Chrisman, 2003, p. 135).

However, some critics have pointed out the limitations of representing exclusively the settler point of view in the depiction of Australia's colonial past. Collingwood-Whittick (2013) argues that "it inevitably causes the transgenerational trauma of Indigenous dispossession to fade, if not from sight entirely, then at least into the periphery of the reader's field of vision” (p. 17).

Grenville tried to justify her choice of not representing the Darug people's consciousness in her writing memoir: "I didn't own that story. It had to be allowed to speak for itself. My job was to get out of its way" (Grenville, 2006, p. 171). Nevertheless, her strategy is still criticized as merely creating "a context where is no acceptance of difference - those that cannot be understood become other" (Healy, 2008, p. 484).

And, the novel's attempt to rewrite a past with postcolonial empathy has also built up tension between history and fiction, and the representation has been questioned by some historians. As Hirst (2006) pointed out, "Grenville ponders what she would have done on the frontier and what sort of person that would have made her. The leading character in her novel is not an 18th-century waterman at all; it is herself” (p. 10).

In this paper, I would argue that the linear structure of a historical novel tends to dismiss the past as something that passed and was settled, and cannot escape the constraints of the western metaphysical discourse which treats the past and the present as an exclusive dichotomy. The "Great Australian Silence" in Australian history cannot be fully broken without considering the Aboriginal people’s perspectives.

\section{The Multiple Perspectives in Carpentaria}

As David Bailey and Stuart Hall (1992) point out, "black signifies a range of experiences, the act of representation becomes not just about decentering the subject but actually exploring the kaleidoscopic conditions of blackness” (cited in Grossberg, 1996, p. 91). In the same way, Aboriginality is not an essentialist category fossilized in a rock age. Carpentaria is a multi-perspective, multi-center narrative, which articulates a myriad of Indigenous realities by weaving the contemporary Aboriginal life in the Gulf of Carpentaria with Indigenous Law and cosmology. Multiple layers of tensions are built up in the novel, both within and without the Aboriginal 
societies. The Pricklebush people are at odds with Uptown whites in Desperance and with the mining company.

The Uptown white people, as "descendants of the pioneer families", "claimed ownership of the town", and "said the Aboriginal was really not part of the town at all” (Wright, 2006, p. 4), whereas the Pricklebush people mocked the Desperanians as people who "had originated from nowhere” (Wright, 2006, p. 57) and “don't even remember their own religion” (Wright, 2006, p. 49).

The town of Desperance prospered because of the mining industry, which "came along with all of its big equipment, big ideas, big dollars from the bank” (Wright, 2006, p. 98), and bought off "e[E]very bit of Uptown humanity" and also the Eastside "traitors who ran down to the mine crawling on their stomach for a job" (Wright, 2006, p. 98). Nevertheless, Will Phantom, the son of Norm Phantom, "the rightful traditional owner" (Wright, 2006, p. 51), along with other members in Mozzie Fishman's religious convoy, sabotages the mine for their desecration of the sacred land.

Divided opinions are also found within the Aboriginal communities represented in the novel. Norm Phantom, Joseph Midnight and Mozzie Fishman were "s[S]tubborn old mules who anchored their respective clans in the sordid history of who really owned different parcels of the local land” (Wright, 2006, p. 426). Intense tension was built around the old wars between the Eastside mob led by Midnight, and Norm's Westside: “The two senior men of the opposite clans never spoke, or acknowledged the other existed. Their language had no word for compromise" (Wright, 2006, p. 380). As "the patriarch and the zealot who grew out of the same Pricklebush thickets” (Wright, 2006, p. 152), Norm Phantom and Mozzie Fishman are also divided in their views. While Norm refused to get involved in any disputes with the Uptown whites or the mine, Mozzie fervently led his convoy on a religious pilgrimage and on their battle against the mine.

Within Norm's family, the rift between father and son is hard to reconcile. Norm refused to get involved in the disputes with the mine and was "too intoxicated with his passion for the sea to abandon it at Will's request" (Wright, 2006, p. 232), but his son Will blamed him for being "so completely satisfied with the status quo" (Wright, 2006, p. 307). Will had "flown the coup" and walked to Eastside to live together with Midnight's granddaughter Hope, which infuriated Norm Phantom, who was "hot with fever for a week" (Wright, 2006, p. 152). To Norm, “Will was never a proper son” (Wright, 2006, p. 233).

To give full voice to these unyielding Indigenous characters and defy the stereotypically static understandings of Aboriginality, mixed genres are adopted in Carpentaria, blending Aboriginal cosmology and legends into a narrative told in the oral tradition, an indispensable means to hand down traditional Aboriginal heritage.

The story-telling style is set up at the beginning of the novel by engaging the readers (or in the oral tradition, listeners, referred to as “you”) as part of the narration:

The ancestral serpent, a creature bigger than storm clouds, came down from the stars, laden with its own creative enormity. It moved graciously - if you had been watching with the eyes of a bird hovering in the sky far above the ground. Looking down at the serpent's wet body, glistening from the ancient sunlight, long before man was a creature who could contemplate the next moment in time. It came down those billions of years ago, to crawl on its heavy belly, all around the wet clay soils in the Gulf of Carpentaria. (Wright, 2006, p. 1)

Here, the Indigenous cosmology is represented by the "ancestral serpent", which defies the spatial boundaries by uniting the sky and the earth, and challenges the time constraints of human history by being present 
from time immemorial. It embodies itself in the form of the snake-shaped river, which "permeates everything" and "is attached to the lives of the river people like skin" (Wright, 2006, p. 2), and equips Pricklebush people with "inside knowledge about this river and coastal region", known as the "Aboriginal Law handed down through the ages since time began” (Wright, 2006, p. 3).

Representing Indigenous knowledge in the form of the fantastic, the magical, or as dream would tend to be fixed by critics within the constraints of magical realism, but this tendency is also a stereotypical understanding of the literary works by Indigenous writers, and can be regarded as one of the "moves that refuse the text's unfamiliarity, its strangeness to a white reader” (Ravenscroft, 2010, p. 195).

Unlike a dichotomized interpretation of magic and reality in the western discourse, the novel blurs the dividing line between magical and rational, and 'insists on the relatedness of the 'real' and what is problematically termed 'magic', a reconfiguring that demands a revaluation of the ways in which the genre of magical realism signifies" (Devlin-Glass, 2008, p. 392). What is labeled as "magical” in the western discourse is entangled with the Aboriginal people's normal life and inheres in the Aboriginal characters' acute senses and ability to communicate with each other across spatial and temporal boundaries.

In a half-sleep, half-wakeful state, the religious leader Mozzie Fishman's hearing capacity extends from "the night owl somewhere in the trees close by", to "the guitars strumming in the drinking camps over on Joseph Midnight's Eastside" in the distance, and "further off still", to the sound of "the sea woman heaving her breasts onto the beach" (Wright, 2006, p. 149).

Normal Phantom and his son Will could feel each other's presence across spatial barriers:

Away from the house, Will felt great throbs of sadness vibrating through the rain from Norm's grief when he discovered Elias. The rain fell over the saltpans and over the sea for hours that night, then Norm heard the oars swashing through the shallows, as Will rowed out to sea. (Wright, 2006, p. 204)

Even the two dimensions of time and space can interact with and transform into each other. A fusion of the temporal and spatial horizons is engendered when the "familiar sounds" of Mozzie Fishman's past "falling from a magician's wand, waving around specks of memory in a trail of glitter" and finally become "millions of flooding, crashing helter-skelter visions in the stars” (Wright, 2006, p. 149).

In the hyperspace where the rational and the normal interact with the magical and the fantastic, the dividing line between the living and the dead is also obscured. The spirits of the dead are always present in the Pricklebushers' daily life. They "saw huge, powerful, ancestral creation spirits occupying the land and sea moving through the town, even inside other folk's houses, right across any piece of the country” (Wright, 2006, p. 59). Also, Mozzie Fishman's religious convoy "breathed so close to the earth, the night might have mistaken them for the spirits of the dead" (Wright, 2006, p. 120).

In the multi-dimensional narrative space, the boundaries between such binary distinctions as past and present, reality and magic, the living and the dead, the mundane and the sacred are challenged and blurred, and the systematic framing of the so-called "magical realism" is dismantled. The adoption of mixed genres in Carpentaria serves to "reactivate the primitive inscription and restore the palimpsest" covered under the metaphysical white narrative (Derrida, 1982, p. 212). Unlike the white writers' attempt to acknowledge a sense of guilt, the Aboriginal perspectives perceive whiteness as difference, as "Other", and focus on the "foregrounding 
of whiteness as an object of critique” (Brewster, 2010, p. 86), which can be quite disconcerting to the white people.

Though the white people inhabit the geographically centered Uptown in Desperance, they are actually besieged by the Eastside and Westside Pricklebush mobs: "So there it was: fringe camps sandwiching Desperance, and nothing better to do with themselves than to sit about watching white folk of Uptown going about their business" (Wright, 2006, p. 46). Under the scrutiny of the Pricklebush people, the Uptown people who are "white like daylight, white like truth, white like virtue" and "has enjoyed the privilege of seeing" would "feel the shock of being seen” (Satre \& MacCombie, 1964/1965, p. 13), and so would the white readers.

\section{Indigenous and Non-Indigenous Conceptions of the Past}

The perceptions of the past from Indigenous and non-Indigenous perspectives are radically different, which can be demonstrated by the depictions of the Aboriginal rock paintings in the two novels.

In The Secret River, Thornhill's villa can be read as a symbol of the colonial empire, and the painted fish in the rock underneath represents the Aboriginal heritage:

Under the house, covered by the weight of Mr Thornhill's villa, the fish still swam in the rock. It was dark under the floorboards: the fish would never feel the sun again. It would not fade, as the others out in the forest were fading, with no black hands to re-draw them. It would remain as bright as the day the boards had been nailed down, but no longer alive, cut off from the trees and light that it had swum in. (Grenville, 2005, p. 316)

Building the villa upon the rock painting is a sign to acknowledge the Aboriginal people's central place in the construction of the national foundational narrative, which is a reconfiguration of the Aboriginal-white relationships, a reworking of the postcolonial stance. Though the color of the fish under the villa "would not fade", it has lost vigor and becomes static and tends to be dismissed as a past cut from the Aboriginal present. Like an artifact in the museum, though appreciated and admired, its significance to the Aboriginal people cannot be revealed. Since "a nation's loss of certainty regarding its moral worth can threaten both national identity and identification with the nation” (Attwood, 2005b, p. 243), the depiction of the rock painting in The Secret River can be considered as an attempt to lay past settler guilt to rest, thus instead of destabilizing the foundational historical narrative, it becomes complicit with it.

On the other hand, what is hidden in the foundation stone of Thornhill's villa is brought into full play on the historical stage by Alexis Wright in Carpentaria:

Will had climbed higher into the hills, until eventually, he came to a large rock cave. Inside, the walls were covered by ancestral paintings telling stories of human history, made and remade by ochre paints, as the forefathers whispered the charter of their land. Will acknowledged their presence, touched the walls in places to embrace the timelessness of his own being. He felt humbled, honored to be in the home of birds, animals and clans people of time passed. (Wright, 2006, p. 182)

The rock paintings represent the forefathers' whisper of "the charter of land" to Aboriginal people, and their power has been revitalized through generations of Aboriginal hands. The boundaries that define past, present and future have collapsed into the "timelessness" Will Phantom felt in touching the paintings. The soul in the rock paintings becomes united with the flesh of the Aboriginal people, and the spirituality represented by the rock paintings connects Aboriginal people to their cosmology and heritage in which the past, the present and the future 
are interactive instead of exclusive, as pointed out by Attwood (2005a):

the history made by Aboriginal people differed in many respects from that of non-Aboriginal scholars. In Aboriginal history-making, the past has been regarded as part of the present and the future of the Aboriginal people, rather than a time that has passed. (p. 15)

In The Secret River, Thornhill's dishonored convict past is something that needs to be discarded and glossed over. When asked about his family history, he invents a new story to fit himself in:

In this place, where everyone had started fresh-born on the day of their arrival, stories were like those shells down on the beach. A crab might live in one for a while, until he grew too big for it, and then he would scuttle around to another, the next size up. (Grenville, 2005, p. 321)

Hodge and Mishra have exposed the identity crisis of the European settlers in their book Dark Side of the Dream: Australian Literature and the Postcolonial Mind (1991): "This now-dominant group jettisoned their European past and in the process they jettisoned their chance of a future, and their culture ossified, just as languages cease to develop when have provincialized and cut off from the center” (p. 15). And this is why the Desperance whitefellas in Carpentaria were depicted as a hopeless and helpless people, who suffered from collective amnesia and insisted that "they originated from nowhere” (Wright, 2006, p. 57), thus denying themselves of any chance to revitalize their past and envision a hopeful future.

Indigenous authors tend to depict the Aboriginal people's "past, present and future as a collective whole" (Mudrooroo, 1990, p. 95). In Carpentaria, the Aboriginal people's consciousness of being connected to their past is reiterated by emphasizing the act of the old Pricklebush people keeping "chronicles of the land hereabouts since time began" (Wright, 2006, p. 48) and the "memory revisions" as "a daily task, a memory tribunal, undertaken with relish by the old people for everyone's matter of concern” (Wright, 2006, p. 51). The Pricklebushers' consciousness of a timeless past is always contrasted with the Uptown white people's denial of their past, who "contrived the waiting for Elias into an honest act of homage to the comings of their forebears" who "had also once, turned up, appearing from out of nowhere" (Wright, 2006, p. 57).

The Uptown white people's collective amnesia of their past and their obsession with a history starting anew on the continent is analogous to Thornhill and other European settlers' newly created identities, and satirized by the Pricklebush people: "People became full-hearted, loving the memories of their personal histories, even if it was an aberration from a history only as old as the cemetery down the road” (Wright, 2006, p. 61), and their history "was just a half-flick of the switch of truth—simply a memory no greater than two life spans"(Wright, 2006, p. 57).

\section{Indigenous and Non-Indigenous Relationships With Nature and Land}

Indigenous and non-Indigenous perspectives also differ greatly in their conceptions of land and nature. From the European settlers' perspective, nature is harsh and hostile to them, and land is to be cultivated and tamed with their hard labor.

In The Secret River, the settlers feel alienated from the surroundings. To gain a sense of security, the European colonizers try to conquer the land and transform it into something they are familiar with. They build up fences and toil in the cultivated fields. They seize different pieces of land and name them after themselves, such 
as “Blackwood’s Lagoon”, “Thornhill’s Point”, “Thornhill’s Creek”, “Millikin’s Inlet” and “Jameson’s Mill” (Grenville, 2005, p. 313). The act of naming, as an “imposition on the landscape” (Carter \& Malouf, 1989, p. 175), legitimated the colonizers' claim of the land based on the doctrine of "terra nullius" and dispossessed the Aboriginal people of the right to their traditionally inhabited land.

Another instance to show the settlers' wish to conquer the land is Sal's garden, enclosed in "a high stone wall”:

Within the wall the ground had been cleared and levelled for Sal's garden. On that bleak rectangle a garden along English lines was planned. Daffodils and roses were planted. Paths were marked out with string and laid with crushed white sandstone in lieu of gravel. It glittered harshly in the light, but it divided the garden up into squares in the way she wanted. Between the garden and the house there was to be a lawn and, on Devine's advice, expensive turf was imported from Ireland. (Grenville, 2005, p. 318)

The revisionist postcolonial stance tries to tease a sense of guilt and unease from Thornhill, who, with "three hundred acres and a piece of paper to prove it was all his”, still feels "an emptiness”, contrasted with Long Jack, who treats the place as "part of his flesh and spirit” (Grenville, 2005, p. 329). And the fate of Sal's garden is also pathetic:

In spite of her care the garden did not thrive. The roses never put their roots down. They clung to life, but were little more than stalk. The daffodils were planted but no trace of them was ever seen again. The turf yellowed and shrivelled and finally blew away in wisps of dry straw. (Grenville, 2005, p. 319)

The emptiness Thornhill feels and the invalidity of Sal's efforts to import an English garden are also instances of the double perspective in the novel, which stands for a postcolonial reconfiguration of the white hegemonic colonial history and acknowledges the subjectivity of the environment, as Thornhill has observed when he arrives on the continent: "This place had been here long before him. It would go on sighing and breathing and being itself after he had gone, the land lapping on and on, watching, waiting, getting on with its own life" (Grenville, 2005, p. 80).

However, too much emphasis is placed on Thornhill's hard work and sentimentality towards the environment, which lends support to the ideologies and mechanisms of oppression characteristic of conquest and colonizaition, and can be regarded as an attempt to legitimize the national identity constructed on the dispossession of the Indigenous people. By setting up fences and building the house into a fortress, Thornhill's family (and the settlers in general) further isolate themselves from nature and land.

Carpentaria, on the other hand, depicts a quite different view of nature and land from the Aboriginal people's perspective. Unlike the white Australians who "focused on ownership, Aboriginals focus on stewardship over land they were part of” (Sheckels, 2013, p. 174).

In Aboriginal people's cosmology, land and nature are spiritually connected to them and can interact with them. Their Dreaming tracks "connect points on the landscape, showing relationships between points", and "are the 'boundaries' that unite” (Rose, 1992, p. 52).

The Pricklebush people believed that the ground underneath them could breathe and groan and it "gave them old clan folk real power" (Wright, 2006, p. 372). Mozzie Fishman, as the Aboriginal religious leader, led his convoy of zealots "along the spiritual travelling road of the great ancestor, whose journey continues to span the entire continent and is older than time itself" (Wright, 2006, p. 119). On their road, "the only sound is the ghostly 
intermittent chime of a single distant bell, ringing out of the ground, echoing throughout the bushlands" (Wright, 2006, p. 119). As "b[B]earers of the feared secret Law ceremony" (Wright, 2006, p. 119), they regarded the pilgrimage as their "ways of renewing the strength of the country" (Wright, 2006, p. 150).

Instead of being alienated by the surroundings, the Aboriginal people were "a[A]t home on the sea, at home on the land” (Wright, 2006, p. 182). They could become invisible people when necessary:

Norm knew that Will could look like a pandanus tree if he wanted to hide. He knew how to melt away into countryside. In a flat stretch of claypan, Will could flatten himself out behind the clumps of yellowing grasses and become caked mud all afternoon while a search party walked all over him. (Wright, 2006, p. 288)

Plants, animals and natural forces all convey messages for the Aboriginal people to decipher, and also serve as their shield or haven against danger or enemies. When Will Phantom tried to hide himself from the mining people's helicopters, the windy night sang for him "through the slender, bow-bent spearwood forest" below where he slept, and " $\mathrm{t}[\mathrm{T}]$ he ghost-white under-leaf of the wax-green foliage of the stick trees became a procession of spirits moving across the soft earth of darkness, protecting the country of the water people” (Wright, 2006, p. 182).

Contrary to the European settlers in The Secret River, who declared possession of land and things in nature by naming them after the settlers themselves, the Aboriginal people show awe to their country, and never named places after themselves. Though "Mozzie claimed the lagoon" (Wright, 2006, p. 426), it was treated as a sacred place and remained unnamed. Normal Phantom regarded himself "the best fisherman that ever breathed" (Wright, 2006, p. 292), but he showed reverence to the sea woman "whose name must not be mentioned because she might be listening, far out at sea, was spinning herself into a jealous rage” (Wright, 2006, p. 276).

In Carpentaria, the Aboriginal people's reverence for and knowledge of their country was sharply contrasted with the white Uptown people's ignorance of nature and land. The white people made wrong judgments by building the town of Desperance on a river's banks, but the river "simply decided to change course" and rendered the town a "waterless port”, spurning "human endeavor in one dramatic gesture” (Wright, 2006, p. 3) and offering "no apologies for its discontent with people who do not know it” (Wright, 2006, p. 2).

When the white people changed a river's name into Normal's River as a sign for "meaningful coexistence" (Wright, 2006, p. 8), the act was ridiculed by the Aboriginal people, even though Norm pretended to accept it and expressed his thanks to the white people. In their mind, "the river only had one name from the beginning of time. It was called Wangala” (Wright, 2006, p. 10). The act of naming the river after Normal Phantom is the same with that in The Secret River, only a sign to show the white people's possessive desire of land and nature.

\section{Intersubjectivity and Sharing Histories}

Though radically different worldviews about history and land were presented in the two novels, glimpses of intersubjectivity between Indigenous and non-Indigenous people can be captured in both of them.

In The Secret River, Blackwood's Place is depicted as a place for intersubjectivity, where the white colonizer and the Aboriginal people could engage in actual dialogue and live peacefully together, even suggesting a kind of romance between Blackwood and the Aboriginal woman. The reconfigured postcolonial stance explored a possible solution for the settlers and the Aboriginal people to coexist, under Blackwood's motto, “Give a little, take a little” (Grenville, 2005, p. 205). This reconfigured perspective represented “Aboriginality” 
as "a field of intersubjectivity in that it is remade over and over again in a process of dialogue, of imagination, of representation and interpretation" (Langton, 1993, p. 33).

Likewise, the friendship between Norm Phantom and Elias Smith in Carpentaria can also be regarded as a typical instance of intersubjectivity between two different cultures. Though Elias had "the same harsh golden skin” (Wright, 2006, p. 49) as the Uptown white folk's own, and suffered from the collective amnesia that inflicted the white people, he shares the same spirituality with the Aboriginal people:

In the minds of the local people there had always been an infallible certainty without evidence or proof of Elias's knowledge which was said to have come from travelling the many seas of the world. It was just so, for the spirits who had stolen his memory had left him the sea. (Wright, 2006, p. 166)

According to old people in Pricklebush, Elias “might be equated with the Dreamtime world” (Wright, 2006, p. 50), and his intimate relationship with Norm Phantom "is deeply significant to the novel's central theme of crossracial entanglement” (Brewster, 2010, p. 96). Sharing Aboriginal cosmology, and expelled by the Uptown white folk, Elias was finally adopted by the Aboriginal community. After Elias's death, Norm took a spiritual journey of intense physical and psychic suffering to return him to sea, and his story "was later put alongside the Dreamtime by the keepers the Law” (Wright, 2006, p. 54).

The sea, as the place where Elias has been deprived of his memory, and the place which he had immense knowledge and deep connections, might be regarded as Elias's home. Norm's journey to return Elias to sea can be regarded as an intense moment of intersubjectivity when Norm not only sought spiritual atonement with Elias, thus "constituting a healing moment for both white Australia and for black/white relations" (Brewster, 2010, p. 97), but also benefited from the intersubjective communion with Elias. With Elias's guidance, Norm relived and reflected on his moments of fight with his wife Angel and his son Will, and Elias "used his death to help an ignorant old man [Norm] find his grandson, to rekindle hope in his own, joyless soul" (Brewster, 2010, p. 307).

While The Secret River attempts to speak into "the great Australian silence" and come to terms with a haunting past, Carpentaria treats the past as something that will never become settled, which always haunts the present and the future, like a phantom.

Though a postcolonial reconfiguration of whiteness in The Secret River acknowledges the Aboriginal people's "centrality in the construction of Australianness", it largely attends to "White voices, White looks, White experience and White needs" (Hodge \& Mishra, 1991, p. 63). The uncertainty in Aboriginal cosmology is inaccessible to a non-Indigenous point of view and cannot be incorporated into the monolithic linear historical narrative.

To the Aboriginal people, their reality is intermingled with the Aboriginal myths and legends handed down through oral traditions, which are embedded in their cosmology and more real than the so-called science and civilization in the western discourse. One "shared history" will "not allow sufficiently for difference" (Attwood, 2005a, p. 185) and denies the myriad Indigenous realities depicted in Carpentaria from multiple perspectives. As J. J. Healy pointed out: "The history of Aboriginal Australia is ... different from that of white Australia. It comes from a different beginning; it occupies a different space in the present; it is moving toward a different future" (1989, p. 293).

Thus, instead of incorporating the Aboriginal history into the white Australia, the concept of "sharing 
histories” identified by Attwood (2005a) is more feasible for a cohabitation of white and Indigenous people. It "tended to regard histories as a collection of narratives told by differently situated or positioned peoples" (p. 189), allowing for an interstice of difference in the interpretations of history and reality, from both Indigenous and non-Indigenous perspectives.

\section{Conclusion}

Gadamar (2000) points out that "the understanding of the Other possesses a fundamental significance", and "to allow the Other to be valid against oneself is not only to recognize in principle the limitation of one's own framework, but is also to allow one to go beyond one's own possibilities, precisely in a dialogical, communicative, hermeneutic process" (p. 284).

By reconfiguring the settler identity, The Secret River acknowledges the Aboriginal people's place in the construction of the Australian state and anticipates a stage on which they are the sole performers. And, Carpentaria functions as the stage for Aboriginal people to perform their particularities and commonalities at the same time, and their appeal to a sovereign pan-Aboriginal nation. The literary imaginary in Australia represented by the two novels gives voice to both Indigenous and non-Indigenous people, and the glimpses of intersubjectivity in these two novels provide an alternative of sharing histories by acknowledging differences and possible ways for people of radically different cultures to understand and connect to each other.

\section{References}

Attwood, B. (2005a). Telling the truth about Aboriginal history. Sydney: Allen \& Unwin.

Attwood, B. (2005b). Unsettling pasts: Reconciliation and history in settler Australia. Postcolonial Studies, 8(3), $243-259$.

Brewster, A. (2010). Indigenous sovereignty and the crisis of whiteness in Alexis Wright's Carpentaria. Australian Literary Studies, 25(4), 85-100.

Carter, P., \& Malouf, D. (1989). Spatial history. Textual Practice, 3(2), 173-183.

Chrisman, L. (2003). Postcolonial contraventions: Cultural readings of race, imperialism and transnationalism. Manchester: University of Manchester Press.

Collingwood-Whittick, S. (2013). Discursive manipulations of names and naming in Kate Grenville's The Secret River. Commonwealth Essays and Studies, 36(1), 9-20.

Derrida, J. (1982). Margins of philosophy. (A. Bass, Trans.). Chicago: University of Chicago Press.

Devlin-Glass, F. (2008). A politics of the dreamtime: Destructive and regenerative rainbows in Alexis Wright's Carpentaria. Australian Literary Studies, 23(4), 392-407.

Gall, A. (2008). Taking/Taking up: Recognition and the frontier in Grenville’s The Secret River. Journal of the Association for the Study of Australian Literature, Vol. Supplement, 94-104.

Grenville, K. (2005). The secret river. Melbourne: Text.

Grenville, K. (2006). Searching for the secret river. Melbourne: Text.

Grossberg, L. (1996). Identity and cultural studies: Is that all there is? In S. Hall and P. du Gay (Eds.), Questions of cultural identity (pp. 87-107). London: SAGE.

Healy, A. (2008). When history changes who we were [Review]. Australian Literary Studies, 23(4), 481-489.

Healy, J. J. (1989). Literature and the Aborigine in Australia (2nd ed.). St Lucia: University of Queensland Press.

Hirst, J. (2006, Mar). Forget modern views when bringing up the past: [1 all-round country edition]. The Australian [Canberra, A.C.T], 20, 10.

Hodge, B., \& Mishra, V. (1991). Dark side of the dream: Australian literature and the postcolonial mind. Sydney, NSW: Allen \& Unwin.

Hutcheon, L. (1988). A poetics of postmodernism: History, theory, fiction. New York: Routledge.

Kossew, S. (2007). Voicing the "Great Australian Silence”: Kate Grenville's narrative of settlement in The Secret River. The Journal of Commonwealth Literature, 42(2), 7-18. 
Langton, M. (1993). "Well, I heard it on the radio and I saw it on the television ...": An essay for the Australian film commission on the politics and aesthetics of filmmaking by and about Aboriginal people and things. Sydney: Australian Film Commission. Mudrooroo. (1990). Writing from the fringe: A study of modern Aboriginal literature. Melbourne: Hyland House.

Ravenscroft, A. (2010). Dreaming of others: Carpentaria and its critics. Cultural Studies Review, 16(2), 194-224.

Rose, D. B. (1992). Dingo makes us human: Life and land in an Aboriginal Australian culture. Cambridge: Cambridge University Press.

Sartre, J., \& MacCombie, J. (1964/1965). The black Orpheus. The Massachusetts Review, 6(1), 13-52.

Sheckels, T. F. (2013). The stolen generations in feature film: The approach of Aboriginal director Rachel Perkins and others. In B. Wheeler (Ed.), A companion to Australian Aboriginal literature. Rochester: Camden House.

Wright, A. (2006). Carpentaria. Sydney: Giramondo. 